Abstracta Iranica Abstracta Iranica

Revue bibliographique pour le domaine irano-aryen

Volume 32-33 | 2013

Comptes rendus des publications de 2009-2010

\title{
Fabrizio Speziale. Les traités persans sur les sciences indiennes: médecine, zoologie, alchimie
}

Suzanne Kurz

\section{(2) OpenEdition}

1 Journals

\section{Electronic version}

URL: http://journals.openedition.org/abstractairanica/40724

DOI: 10.4000/abstractairanica.40724

ISSN: 1961-960X

Publisher:

CNRS (UMR 7528 Mondes iraniens et indiens), Éditions de l'IFRI

\section{Printed version}

Date of publication: 1 December 2013

ISSN: 0240-8910

\section{Electronic reference}

Suzanne Kurz, «Fabrizio Speziale. Les traités persans sur les sciences indiennes: médecine, zoologie, alchimie », Abstracta Iranica [Online], Volume 32-33 | 2013, document 405, Online since 01 July 2016 , connection on 03 October 2020. URL : http://journals.openedition.org/abstractairanica/40724 ; DOI : https://doi.org/10.4000/abstractairanica.40724

This text was automatically generated on 3 October 2020.

Tous droits réservés 


\title{
Fabrizio Speziale. Les traités persans sur les sciences indiennes: médecine, zoologie, alchimie
}

\author{
Suzanne Kurz
}

\section{REFERENCES}

Fabrizio Speziale. « Les traités persans sur les sciences indiennes: médecine, zoologie, alchimie ", in : Denis Hermann \& Fabrizio Speziale, eds., Muslim Cultures in the IndoIranian World during the Early-Modern and Modern Periods. Téhéran - Berlin, Institut Français de Recherche en Iran - Klaus Schwarz, 2010, p. 403-447. (Bibliothèque Iranienne, 69 - Islamkundliche Untersuchungen, 290)

1 This article on Persian treatises on Indian medicine, zoology and alchemy is much more than its modest title suggests. The author starts by reevaluating current views in the history of medicine about a decline after the end of the Abbasid period. A sophisticated picture is drawn of developments and trends in medicine and related sciences in Muslim India. In contrast to Cyril Elgood, Speziale argues that, although Persian translations and commentaries of classical Arabic works were not produced in large numbers before the 16th century, the original works were widely read in India. He considers the medical texts in Persian and Urdu written in India during the Mogul and colonial periods to be one of the richest corpora of texts in Muslim culture at the time.

2 In the first paragraph, Speziale traces Indian knowledge in the works of Muslims back to Abbasid Baghdad, citing several examples such as the section on Indian medicine in 'Alī b. Sahl Rabban al-Tabarī's Firdaus al-hikma. But he also states that such works seem to have had no influence on the Persian works about Indian medicine written later in India. About the translations from Sanskrit into Persian already in progress in preMogul India, Speziale points out that the process of appropriating Indian knowledge was much slower than the integration of Greek knowledge into Arabic literature, but 
that it lasted much longer. The author then focuses on the interest in Indian medicine, the forms of appropriating knowledge, the relation between Muslim traditions and Indian knowledge, and the Indian medical milieu. The interest in Indian medicine and drugs mainly stemmed from practical considerations, from the need to adapt Avicennian medicine to the Indian environment. The remark is insightful that new knowledge was appropriated mainly by composing new works in Persian and seldom by direct translation from Sanskrit sources. Worth mentioning too is the finding that native Indians - more often Muslims than Hindus - mostly produced the corpus of new Persian texts, whereas written by Iranian emigrants to India made the early Persian translations and commentaries of classical Arabic texts, such as Avicenna's Qānūn. This comprehensive overview of trends and developments in the field of medicine is followed by four instructive paragraphs about major works in pharmacology, sexology, physiognomy, zoology, veterinary medicine and alchemy. The last paragraph is devoted to the developments during the colonial period. The author draws the conclusion that many of the new topics pointed out in this article demand more research. Given the lack of research on the history of sciences in Muslim India, we can but agree with this conclusion.

\section{AUTHORS}

\section{SUZANNE KURZ}

Ruhr-Universität, Bochum 